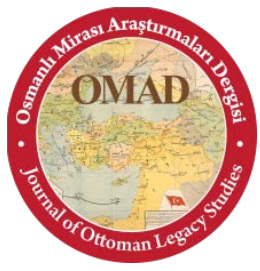

Osmanlı Mirası Araştırmaları Dergisi (OMAD), Cilt 3, Sayı 7, Kasım 2016, ss. 133-143.

Journal of Ottoman Legacy Studies (JOLS), Volume 3, Issue 7, November 2016, pp. 133-143.

ISSN 2148-5704

DOI Number: 10.17822/omad.2016.48

\title{
BRITTANYA İMPARATORLUĞU SAVAŞ KAMPLARINDA ESİR DÜŞEN BATI RUMELİ ASILLI OSMANLI GÖNÜLLÜLERİ (1916-1923)
}

\author{
Rumelian Ottoman Volunteers in British P.O.W. Camps (1916-1923)
}

\section{Redžep ŠKRİJELJ*}

Özet: Doğu cephesindeki başarısızlıklar, 1916 yılının Avusturya-Macaristan için askerî açıdan en zor yıllardan biri olduğunu kanıtlamıştır. İtilaf Devletleri Rusya'nın yanı sıra İtalya ve Romanya tarafindan desteklenmiş olduğu için Avusturya-Macaristan askerî birlikleri birkaç cephe arasında püskürtülmüştür ki böyle bir durumda personel ve kadro açısından yardıma ihtiyaç görmüştür. $\mathrm{Bu}$ arada Almanya İmparatorluğu askerî güçlerini Batı Cephesi'nde yoğunlaştırdığı için Avusturya-Macaristan devleti askerî yardım için diğer İttifak Devletlerine başvurmak zorunda kalmıştır. Avusturya-Macaristan mücadele birliklerini kuvvetlendirmek maksadıyla yapılan şiddetli askerî propaganda sonucu olarak 1916 sonbaharı ve 1917 ilkbaharı arasında Galiçya Cephesi’ne XV. Osmanlı Kolordusu kapsamında 10 bin gönüllü ve acemi asker gönderilmiştir. Osmanlı Askerî Karargâhı böyle bir kararı Balkanlar üzerinden Anadolu'ya Rus işgalini önlemek için getirdiğini savunmuştur. Kötü örgütleme, disiplinsizlik, zayıf giyim, açlık, büyük sayıda yaralı ve engelli, bulaşıcı hastalıkların salgını esnasında aşı yetersizliği askerlerin morallerini yitirmiştir. Çok sayıda ölü ve esir veren Osmanlı askeri, Avrupalı müttefiklerini karşılamak için Galiçya, Romanya ve Selânik Cephelerinde ikinci sıradan görevler yapmak zorunda kalmıştır. Avusturya, Alman, Yugoslav, Sırp, Britanya ve Osmanlı arşivlerinde bulunan kaynaklardan Galiçya, Kafkas, Çanakkale, Filistin, Suriye ve Arabistan cephelerinde kanlı ve şiddetli mücadele gören çok sayıda Rumelili gönüllü Britanya savaş kamplarında esir kalmıştır. Sırp, Hırvat ve Sloven Krallığı Dışişleri Bakanlığı tarafından hazırlanan raporlara göre AvusturyaMacaristan ve Bulgar işgalci iktidarı tarafından çok sayıda genç erkek 1917 yılı boyunca seferber edildikten sonra Suriye'ye gönderilmiş ve o bölgede İngilizlerin eline esir düşmüştür. Savaşın sonunda Britanya iktidarı 3 bin Müslüman gönüllüyü Rumeli'den İstanbul'a tehcir etmiş, onlar da evlerine geri dönebilmek için Yugoslav Hükûmeti Konsolosluğuna başvurmak zorunda kalmıştır. Uzun süren bu ağır savaş, esirler için hayatta kalma mücadelesi idi. Çok sayıda savaş gazisi Makedonya, Kosova ve Sancak'a yaralı ve hasta durumda dönerek parasızlığa ve açlığa mahkûm olmuştur. Gönüllülerin geri dönüşleri uzun yıllar sürmüştür. Yeni kurulan Sırp, Hırvat ve Sloven Krallığı içinde yaşayan eski Müslüman gönüllülerin daha sonraki yıllarda Çetnik birlikleri tarafindan katledilmiştir. Savaş gazilerinin büyük bölümü Mısır'da bulunan Britanya askerî kamplarından ağır fiziksel yaralarla ve psikolojik travmalarla geri dönmüştür. Kampları

Anahtar Kelimeler: Osmanlı Gönüllüleri, Batı Rumeli, Birinci Dünya Savaşı, Galiçya, Britanya Savaş

Abtract: The low success on the Eastern Front had shown the year of 1916 as the most difficult for AustriaHungary. The strenghtening of the Antanta which was additionally supported by Italy and Romania resulted in dispersing of the Austrian-Hungarian Army on the fronts, and was forced to fight on multiple theaters of war and needed more manpower. Since Imperial Germany transfered all of its troops to the Western Front, Austria-Hungary was forced to request the company of their Ottoman allies to successfully accomplish their war efforts. The improvement of Austro-Hungarian military positions requested a ruthless war propaganda during the period between the fall of 1916 and the spring of 1917 when the XV Ottoman Corpse containing 10 thousand volunteers and recruits has left for the Galician Front. The Ottoman Military explained their excursion to Galicia as a defensive effort against a possible Russian invasion of the Balkan Peninsula. Circumstances which included bad organization, poor discipline, lack of clothes, hunger, a great number of injured and disabled soldiers, lack of vaccines against infectious diseases affected the moral of the volunteers. The triumphant Ottoman Volunteer Army assissted its European allies by accomplishing secondary war maneuvers at the Galician, Romanian and Macedonian Front which costed them many martyrs and prisoners of war. The extensive documentation from Austrian, German, Yugoslav, Serbian, British and Ottoman archives we can detect a large number of Rumeli Volunteers ending up in British P.O.W. camps which previously joined the intense fightings at the Galician, Caucassus, Dardanelle, Mesopotamian and Arabian war

* (Prof. Dr.), Novi Pazar Devlet Üniversitesi, Novi Pazar/Sırbistan, e-mail: rekasancak@gmail.com 
theaters. According to the reports of the Ministry of Foreign Affairs of the Kingdom of Serbs, Croats and Slovenes, a huge portion of them was recruited and deported by the Austro-Hungarian and Bulgarian occupation authorities which deported them to areas of Mesopotamia where they eventually became British prisoners of war. By the end of the war more than 3 thousand Muslim volunteers from Rumelia were deported to Istanbul where they applied to Yugoslav authorities with a request for readmission into their homeland. For these prisoners of war, the difficult war was transformed into a difficult fight for survival and return to their families. Many war veterans have returned to Macedonia, Kosovo and Sanjak wounded, carrying diseases, without material support, food and water. Their return has lasted for many consequent years. A huge number of them were molested and murdered by the Serbian Chetnik formations because of the Ottoman Turkish uniforms they had been wearing. A large portion of the volunteers have returned from the British P.O.W. camps in Egypt burdened by serious physical and psychological trauma.

Keywords: Ottoman Volunteers, Rumelia, World War One, Galicia, British P.O.W Camps

\section{Giriş}

Osmanlı Devleti’nin Balkan Savaşları (1912-1913) sonucu güç kaybetmesi Avrupa topraklarından çekilmesine ve küçülmesine sebep olduğu için İmparatorluk'a sadık kalan Rumelili Müslüman nüfusu tehlike, güvensizlik, şaşkınlık ve belirsizlik içinde kalmıştır. 'Balkanlar, Balkan milletlerine aittir.' ${ }^{1}$ ilkesi eski Osmanlı topraklarında yaşayan Müslüman nüfusunun bu alanlardan kovulmasını ve Osmanlı askeriyle birlikte Anadolu'ya göç ettirilmesini beraberinde getirmiştir. Evlerini terk eden bu nüfusun kültürüne ait bütün izlerin silinmesi de bu sürecin bir diğer olumsuz tarafıdır. ${ }^{2}$

Yeni kurulmuş Balkan devletçiklerin hiçbiri, yeni işgal ettikleri topraklarda yaşamaya devam eden Müslüman nüfusun ihtiyaçlarını karşılamaya gerek duymamıştır. Osmanlı İmparatorluğu'nun mağlubiyeti ile birlikte Balkan Hristiyan devletlerinin ortak düşmanı ortadan kaldırılmıştır. Yeni sınırların da bu şekilde çizilmesiyle Rumeli Müslümanları hâkim unsurundan anavatanları Avrupa'da kendi kaderini tayin hakkına bile sahip olmayan bir gruba dönüşmüştür. $\mathrm{Bu}$ olaylar esnasında 1913 yılının Mayıs ayında Londra'daki Avrupa büyük güçleri, Balkanlar'daki Rus vasal ülkeleri olan Sırbistan ve Karadağ'a, orada yaşayan nüfusun isteğini ${ }^{3}$ tartışmadan Sancak, Kosova ve Makedonya topraklarını teslim etmiştir. İşgal edilen topraklarda yeni kurulan Balkan Hristiyan ülkeleri, Müslümanlara, sorunlarını çözmeleri veya tamamen göç etmeleri ${ }^{4}$ için dört yıllık zaman vermiştir. Verilen garantilerin yanı sıra, yeni koşullarda sürdürülen hayat din özgürlügünü, eğitim ve kültür gelişimini serbest bırakmamıştır.

Panslavizm ve Ortodoks köktendinciliği temelleri üzerine dayanan Balkan devletlerinin saldırgan Hristiyan milliyetçiliği, Batı Rumeli topraklarında yaşayan Müslüman topluluğunun hayatta kalmasını tehdit etmeye başlamıştır. Yunan 'Megali İdea' fikrinin yanı sıra Güney Slavların Piyemontesi olan, Adriyatik Denizi'nden Karadeniz'e uzanan 'Büyük Sirbistan' fikri sürekli desteklenmiştir. Sırbistan Krallığı'nın işgalci iktidarı Sancak, Kosova ve Makedonya topraklarında etnik yapıyı değiştirmek amaçlı bir politika yürüterek Müslüman nüfusunu asimile etmiştir. ${ }^{5}$

Sadece iki yıl sonra, Avusturya-Macaristan'ın saldırgan askerî hareketleri sonucu, Birinci Dünya Savaşı'nın başlaması Batı Rumeli'de çözülmemiş sorunları tekrar gündeme getirmiştir. Savaş, halk arasında korku ve dehşet yaratmıştır. Sırbistan'ın yenilmesi Müslüman nüfus içinde

\footnotetext{
${ }^{1}$ Aleksić-Pejaković Lj., Balkan balkanskim narodima - između legitimističkog i nacionalnog principa, bakını: Zbornik: "Balkan islam i velike sile”, Beograd 1998.

2 Abidin Temizer, "Şiirsel Gerçeklikten Tarihî Gerçekliğe Balkan Uluslarının Bağımsızlık Çözümlemesi: Hakkın Sesleri”, Uluslararası Mehmet Akif Ersoy Sempozyumu, Sanatı-Kişiliği-Milli Mücadeledeki Yeri (Bildiri Kitabı), Balıkesir 2011, s. 354-6.

${ }^{3}$ A. Bebler, Propuštena prilika za istorijski sporazum, u: Helsinška povelja, no. 119-20., Beograd maj-juni 2008, s. 16; Abidin Temizer, "Montenegro in the First Balkan War“, Annals Series on History and Archeology, Vol. 5, Issue 1, 2013, s. 76.

${ }^{4}$ H. Halid, Borba polumjeseca i krsta, knj. (kitap) I, Mostar 1913, s. 187-9; Abidin Temizer, "Karadağ'da Öteki Sorunu: Müslümanlar“, History Studies, Vol. 5, Issue 3, May 2013, s. 225-37.

${ }^{5}$ Safet Bandžović, Iseljavanje Bošnjaka u Tursku, kitap. 1, Sarajevo 2006, s. 243-4.
} 
Osmanlı İmparatorluğu'nun geri dönmesi umudunu yeniden canlandırmıştır. Uzun süren savaş propagandasının bir sonucu olarak Müslüman nüfus arasında Osmanlı İmparatorluğu müttefikleri olan Avusturya-Macaristan ve Almanya İmparatorluğu askerlerine katılma isteği doğmuştur. Askerî ve siyasi durumun bileşik şekilde gelişmesi buradaki Müslümanların bir bölümünü tekrar göçe zorlamıştır.

\section{Gönüllülerin Savaş Yılları}

$\mathrm{Bu}$ dönemde en önemli gelişme Avusturya-Macaristan ve Bulgaristan askerlerinin 1915 yılının sonlarına doğru tamamladığı işgal ve savaş gönüllüleri seferberliğinin başlamasıdır. ${ }^{6}$ En çok kullanılan propaganda iddiaları arasında Birinci Dünya Savaşı'nın Müslümanların yok edilmesi için başlatıldığıdır. Rumeli Müslümanları kamuoyunda böyle haberler İttifak Devletleri tarafına geçen Osmanlı İmparatorluğu'nun Balkan Yarımadası'na geriye döneceği yönünde boş beklentileri uyandırmıștır. Kısa zaman içinde ordu birlikleri Romanya, Bulgaristan, Arnavutluk, Kosova, Sancak ve Makedonya topraklarından seferber edilen Müslüman gönüllüleriyle doldurulmuştur. Bunlar müttefikler tarafindan Galiçya, Gelibolu, Anadolu, Romanya, Irak, Filistin, Suriye ve Kafkas cephelerine dağıtılmıştır.

Osmanlı Sultanı Mehmed Reşad, Kasım 1914 ve 16 Şubat 1915 tarihlerinde gönderdiği cihat çağrısında Batı Rumeli Müslümanlarını kastetmemiştir. Buna rağmen Balkanlar'da yaşayan nüfus savaşa gönüllü olarak katılabilmek için büyük ilgi göstermiştir. İttifak Devletleri'ne katılan Bulgaristan Çarlığı, Birinci Balkan Savaşı'nda (1912-1913) Batı Rumeli'de ele geçirdiği Selânik, Manastır ve Kosova vilayetleri üzerinde kontrolünü garanti altına aldıktan sonra Müslüman gençlerini Osmanlı müttefik ülkelerinin katıldığı cephelere göndermeye hak kazanmıştır. ${ }^{7}$ Buna benzer örnekler arasında Kosova vilayetinin bir şehri olan Prizren'de Ağustos ve Ekim ayları arasında açık olan askerî makama çok sayıda yerel genç erkeğin ilgi gösterdiği belirtilebilir. ${ }^{8}$

Sancak, Kosova ve Makedonya'da yapılan şiddetli propaganda sonucu 18 ve 50 yaş arasında çok sayıda gönüllü toplanmıştır. 'Din ve iman için've 'Türk adı taşıyan herkes derhâl gönüllülere katılsın' 9 sloganları kullanılarak Yeni Pazar, Tutin, Rojaye, Bijelo Polje (Akova), Pljevlja (Taşlıca), Prepol, Kosova Mitroviçası, Ferizovik, Prizren, İpek, Üsküp, Kalkandelen ve diğer bölgelerden çok sayıda gönüllü gencin seferberliğe iştirak ettiği görülmektedir. Seferberliğe katılan erkeklerin büyük bir bölümü özel gönüllü askerî birlikleri ${ }^{10}$ arasında yer aldıktan sonra XV. Osmanlı Kolordusu'nun parçası olarak Doğu Avrupa Cephesi'ne gönderilmiştir. Gönüllüleri bu topraklara gitmeye ikna etmek için kolaylaştırılmış askerî hizmet, savaştan sonra büyük ödüller, zengin hayat ve yüksek rütbeler vaat edilmiştir.

1916 y1lı Ekim ayından itibaren Makedonya Cephesine, Rumeli’den gelen gönüllülerden oluşturulmuş 177. Osmanlı Piyade Birliği mücadele etmiştir. ${ }^{11} \mathrm{Bu}$ birlik, Veles (Köprülü) şehrine girerek çok sayıda gönüllü askeri seferber etmiş ve yerel nüfus tarafindan kahramanca uğurlanmıştır. ${ }^{12}$

Avusturya-Macaristan askerî temsilcileri tarafından, 2 Kasım 1916 tarihinde Osmanlı Ordusu Genel Karargâhına gönderilen raporda, Avusturya-Macaristan işgali altındaki topraklarda Cevat Çobanlı komutasında bulunan XV. Osmanlı Kolordusu'na 3.954 Müslüman

\footnotetext{
${ }^{6}$ Omer Koničanin, Sjećanja, Istorijski arhiv,, Ras, Novi Pazar 1988.

${ }^{7}$ Arhiv Jugoslavije, Beograd/ Yugoslavya Arşivi, Belgrad, Fond/Dizi: AJ 370-57-245; 370-6-112; 370-52-134; 37051-133.

${ }^{8}$ Arhiv Jugoslavije, Beograd/ Yugoslavya Arşivi, Belgrad, Fond/Dizi: AJ 370-57-245; 370-58-533; 370-6-88.

${ }^{9}$ Omer Koničanin, Sjećanja ... s. 111.

${ }^{10}$ Ejup Mušović, Etnički procesi i etnička struktura stanovništva Novog Pazara, Etnografski institut SANU, Beograd 1979, s. 106

${ }^{11}$ Arhiv Jugoslavije, Beograd/ Yugoslavya Arşivi, Belgrad, Fond/Dizi: AJ 370-6-112-116.

12 Hasib Saygılı, "Birinci Dünya Harbinde Rumelinden Osmanlı Ordusuna Müslüman Gönüllü Katılımları", Hacettepe Türkiyat Araştırmaları, 18 (2013), s. 242.
} 
gönüllünün seferber edildiği bildirilmektedir. Bulgaristan işgali altındaki bölgelerde yapılan seferberliklerle birlikte toplandığında bu sayı olağanüstü rakamlara ulaşmıştır.

Rastlantı sonucu olarak Sırp ordusu tarafindan zorla seferber edilmiş fakat kısa bir zaman içinde Avusturya-Macaristan ordusu tarafından esir alınan Müslümanlar derhâl benzer birliklere gönderilmiştir. Belgrad'ta Osmanlı askerî temsilcisinin raporuna göre, 20 Mayıs 1917 tarihine kadar Novi Pazar ve Prepol bölgeleri arasında 800 Müslümanın gönüllülere katıldığ anlaşılmaktadır. Bunların, 200 kişilik gruplar hâlinde Belgrad üzerinden İstanbul'a gönderileceği belirtilmiştir. ${ }^{13}$

Resmî bir kaynağa göre XV. Kolordu birliklerinde, Taşlıca ve İpek bölgesi arasında seferber edilen 50 ve 60 yaş civarında olan gönüllülerin arasında 14 veya 15 yaşındaki çocuklar da yer almıştır. ${ }^{14}$

Galiçya Cephesi'ne gideceklerini bilmelerine rağmen, çoğunluğu bu çağrıyı Türkiye'ye karşı borçları olarak anlamıştır. Bunun 'Gerçek Bir Türk Savaşı' olmadığını öğrenenler, aldatıldığını hissetmiştir. Hayatını kaybetmiş ve evlerine engelli veya yaralı olarak dönmüş çok sayıda askere rağmen, Avusturya-Macaristan Yerel Askerî Komutanlığı'nın (Alm. Kreiskommando-K.u.k) kararıyla, yerel soylular, ağalar ve beylerin yardımı vasıtasıyla yeni zorunlu seferberlik süreci başlatılmıştır. Çok sayıdaki hile, rüşvet ve değişimler ile nüfusun en zengin tabakası kayırılmıştır. Yerel belediye görevlileriyle birlikte hazırlanan uzun listelere 2 bin kişinin adı kaydedilmiştir. Rojaye bölgesinde bile zorla seferber edilen 500 asker Galiçya Cephesi'ne gönderilmiştir. Resmî bir rapora göre Taşlıca ve İpek bölgeleri arasından seferber edilerek Galiçya'daki XV. Kolordu'da sevk edilen Müslüman gönüllüleri Yeni Pazar ve diğer bölgelerde yaşayan nüfus tarafindan "zorunlu" sıfatıyla adlandırılmıştır. Bunların hepsi anavatanını topluca terk etmiştir. Aynı yıl içinde sadece Müslümanların ödemek zorunda olduğu "gönüllü vergisi” getirilmiştir.

Çok sayıda genç insanın, ateş hattına gönderilmesi ekonomiyi ve nüfusu olumsuz şekilde etkilemiştir. Avusturya-Macaristan işgali (Kasım 1915-1918) bu bölgenin tarihinde en ağır dönemlerinden biri olarak hatırlanmıştır. Halk arasında "Alman" yılları olarak bilinen bu dönemde büyük kuraklık, lekelihumma, "İspanyol" gribi ve kolera salgınları ile önceden görülmemiş kıtlık yaşanmıştır. ${ }^{15}$ Çok sayıda sivil ve askerin hayatını kaybetmesine neden olan savaş, kıtlık ve salgın nedeniyle genel bir felakete dönüşmüştür.

\section{Britanya Kamplarında Boşnak Esirleri}

Birinci Dünya Savaşı sırasınca İtilaf Devletleri (Avusturya-Macaristan, Almanya, Osmanlı İmparatorluğu, Bulgaristan) ile İttifak Devletleri orduları arasında iki yıl boyunca sürdürülen savaşlar sırasında çok sayıda gönüllü asker seferber edilmiştir. 1916-1917 yıllarında Sultan Mehmed Reşad'ın göndermiş olduğu cihat çağrısına çok sayıda Boşnak ses vermiştir. 1878 ile 1912-13 dönemi boyunca Osmanlı topraklarına kalıcı olarak taşınan düzenli orduda yer alan muhacirlerin yanı sıra, Osmanlılar tarafında mücadele edebilmek maksadıyla çok sayıda Yeni Pazar Sancaklı Boşnak da katılmıştır.

Savaşın sonuçlarından biri de belirli sayıda Boşnak gencin Sırp askeri tarafından zorla seferber edilmesidir. Osmanlı ordusunun, savaş mevkilerinden Galiçya Cephesi'nden diğer savunma cephelerine doğru yer değiştirmesi de çok sayıda askerin esir alınmasına ve sivil kaybına sebep olmuştur. Sırbistan Krallığı ve Karadağ Krallığı topraklarının AvusturyaMacaristan ve Bulgaristan tarafından iki işgal bölgesine ayrılması, Bulgar iktidarı tarafından

\footnotetext{
${ }^{13}$ H. Saygili, a.g.e., s. 239.

${ }^{14}$ Akçakayalığlu Cihat, Birinci Dünya Harbi, C. VII - Avrupa Cepheleri, 1. kısım (Galiçya Cephesi), Genelkurmay Başkanlığı, Ankara 1967, s. 87.

${ }^{15}$ Redžep Škrijelj., "Đurumlije - Sanjak Bosniak Volunteers in the Turkish Military Orders from Gallipoli to Galicia (1916-1918)”, Bakını: Bosnia \&Hercegovina - International Balkan Annual Conference (IBAC), Kitap serisi. 3, İstanbul 2015, s. 225.
} 
belli sayıda askerin müttefik cephelerine taşınmasını sağlayıp daha sonra Britanya ordusuna (Şam, Bağdat, Basra, Nablus, Kahire) esir düşmesini ve Mısır kamplarında zorunlu şekilde çalıştırılmasını sağlamıştır. ${ }^{16}$

Sırbistan Arşivi ve Yugoslavya Arşivi tarafından hâlâ yayımlanmamış arşiv malzemelerinde görüldüğü üzere çok sayıda Müslüman gönüllünün Anadolu ve Yakın Doğu cephelerine gönderilmesi, Mısır'daki Britanya savaş kamplarında esir düşüp en ağır fiziksel işlerle uğraşmalarına yol açmıştır.

Savaş sona erince Britanya hükûmeti savaş esirlerini peyderpey serbest bırakarak, besin ve uygun giysi sağlamadan İzmir, İstanbul ve Selânik şehirlerinde yeni kurulmuş Sırp, Hırvat ve Sloven Krallığı konsolosluklarına taşımıştır. Bilahare bu kişiler ülkelerine geri dönebilmek için bağlı bulundukları diplomatik temsilciliklerden izin almak zorunda kalmışlardır. Bunlar arasında Sancak'a değişik şekilde geri dönmeye çalışan çok sayıda esir ve seferberliği kaldırılmış Boşnak bulunuyordu.

Elimizdeki arşiv malzemelerini temel bilgi kaynağı olarak aldığımızda, arasında Yeni Pazar Sancak'ından gelen birkaç yüz Boşnak'ı bulunduran, en az dört bin Rumelili Müslüman diplomatik temsilciliklerinin kapıları önünde durup ana vatanlarına geri dönme talepleriyle aylar boyunca cevap beklemiştir.

Diplomatik yazışmalara baktığımızda bu kişilerin isteklerine ulaşmada oldukça seçkin usullerin kullanıldığını görebiliriz. Gönüllüler, evlerine ve ailelerine dönmek için oldukça isteklidirler ancak döndüklerinde akıbetleri hususunda endişe ve korku taşımaktadırlar. Örneğin 4 Aralık 1919 tarihinde Sırbistan Dışişleri Bakanlığı Siyasi Dairesinden İstanbul Krallık Temsilciliğine gönderilen mektupta M. Gavriloviç: "Türk ordusundaki askerlerin ülkelerine geri dönmelerine izin vermeliyiz. Buraya geldikten sonra vatandaşlarımı olmalarına rağmen düşman ordularında gönüllü olarak yer aldıkları için yargılanmaları tekrar gözden geçirilecektir." sözleri bu endişeyi haklı çıkarmaktadır.

Genelde Türk sıfatını taşıyan her şeye karşı nefret içeren Sırp memurları tarafindan yürütülen Sırp, Hırvat ve Sloven Krallığı diplomatik temsilcilikleri, eski ve kopuk Osmanlı üniformalarıyla çok sayıda savaş gazisinin yürüyerek veya kaçak şekilde ülkelerine dönmesine izin vermemiştir. Sancak'a doğru ağır ve belirsiz dönüş seyahatini anlatan Peşter bölgesindeki Raşkoviçe köyünden gelen Abdulah-Dule Muratoviç'in sözlerine göre: “Gönüllü olarak Suriye'deki Halep'e ulaştık. Burada bir yıl geçirdik. Hiç bulut görme şansım olmadı. Yağmurun yağdı̆̆ını bile göremedik. Böyle bir iklime uyum sağlamamız zordu, fakat açlık, yorgunluk ve hastalıklar her gün yeni ölümlere sebep oluyordu. Evlerimize geri döndügümüzde askerî elbiseden başka giyecek eşyamız kalmamıştı. Geri dönüşümüz esnasında güvenlik açısından büyük zorluklarla karşılaşmıştık çünkü yolu bilmiyorduk. 1919 yılı boyunca sicaktan ve yoldaki tehlikelerden dolay yolculuğu geceleyin yapmaya, gündüz ise mısır tarlalarında saklanmaya karar verdik. Sonuçta Isştip şehrindeki bir beyin evine kabul edilmiştik. Türk üniformamızdan dolayı güzel şekilde karşılandık. ${ }^{17}$

Çok sayıda gönüllü, vatanlarına hiç dönememiş, hayatta kalanlar arasında ise Anadolu ve Yakın Doğu bölgelerinde yerleşenlerin de sayısı önemliydi. Geri dönmeye karar veren gönüllüler ise vatanlarına ulaşabilmek için Hristiyan nüfusu barındıran, özellikle İbar Vadisi'nden geçmek zorunda kalmıştır. Savaş sonrasında Sırp ve Karadağlı teröristler tarafından Müslümanlara karşı yapılanlar esnasında suç işleyenler mahkemeye getirilmemiştir. Böyle bir durum Ramiçeviç kardeşlerinin cinayeti örneği ile anlatılabilir. $\mathrm{Bu}$ üç kardeş Kosova Mitroviçası ve Ribariçe yerleşim yerleri arasında bulunan İbar Kolaşin bölgesinden geçişleri sırasında öldürülmüştür.

\footnotetext{
${ }^{16}$ R. Škrijelj, a.g.e., s. 226-7.

${ }^{17}$ Redžep Škrijelj, Sandžački Bošnjaci u Makedoniji (1918-1945), Eserin adı: Seobe kao sudbina, Istorijska čitanka za potomke bošnjačkih muhadžira u Makedoniji, Citypres, Skopje 2011, s. 317.
} 
Yine gönüllülerin büyük bölümü ise kötü yaşam koşulları nedeniyle, yorgunluk ve salgın sonucu ölmüştür. Bazıların ise "izi kaybolmuştur." Geri dönmeyi başaran, Goduşa köyünden gelen gönüllü asker Reşo Duroviç’in sözlerine göre çok sayıda silah arkadaşı Kahire'deki esir kamplarında yaralanıp yaşamını yitirmiştir. Kendisi gemide çalışmış ve ölen savaş esirlerinin gömülmek yerine denize atıldığına şahit olmuştur. Hayatta kalanların vatana geri dönmeleri, savaş zorluklarından, birkaç yıl boyunca devam etmiştir. Balkan Savaşları sonucu Sırbistan ve Karadağ Krallıkları arasında bölünen Sancak bölgesinden gelen bu gönüllüler, anavatanlarının toprakları üzerinde yeni kurulan devletlerin askerlerini ve devletini işgalci güç olarak algılamıştır. $^{18}$

\section{Esir Kalan Rumeli Gönüllüllerinin Akıbeti}

Birinci Dünya Savaşı'nın sona ermesi savaşa gönüllü olarak katılan askerler ve esirler için yeni sorunlar getirmiştir. Savaş sonucu daha da güçleşmiş olan iletişim ve genel bilgisizlikten dolayı gönüllü askerler ve aileleri arasındaki bağlantılar kötü yönde etkilenmiştir. Cenevre'de Uluslararası Kızılhaç Komitesi tarafından Uluslararası Savaş Esirleri Ajansı kurulmuştur. Bu kurul vasıtasıyla savaşa katılan devletler karşılıklı olarak savaş esirleri, asker ve sivillerle ilgili bilgi paylaşımında bulunmuşlardır. Bu yazışmaların ve seferberliği kaldırılan asker ve gazilerin dilekçeleriyle İstanbul ve İzmir'deki Sırp, Hırvat ve Sloven Krallı̆̆ diplomatik temsilcileri tarafından vatana geri dönmeleri için gerekli bilgi ve araçlar hazırlanmaya başlamıştır.

Elimizde olan istatistiklere göre Galiçya, Romanya ve Makedonya cephelerinde Osmanlı Ordusunda mücadele eden Batı Rumelili ${ }^{19}$ gönüllülerin sayıs1 40 bini aşmıştır. Bunların büyük bir bölümü (Galiçya Cephesi'nde 20 bin civarında) düşman orduları eline düşüp esir kamplarına götürülmüştür. Osmanlı Ordusu, durumu ailelere bildirmek için elinden geleni yapmış fakat bu süreç zorlukla gerçekleşmiştir. Bu esirlerin serbest bırakılması 15 Aralık 1917 tarihinde başlayan ateşkesle birlikte Sovyet Bolşevik Devrimiyle gelişen siyasi krizin devam etmesi sonucu olarak 17 Eylül 1921 tarihinde Moskova'da imzalanan antlaşmayla kesinleşmiştir. ${ }^{20}$

Galiçya, Romanya, Gelibolu ve Kafkas Cephelerinde esir düşüp Britanya savaş esirleri kamplarına nakledilen gönüllü askerlerin çektikleri zorluklar burada da devam etmiştir. Bunların bazıları daha da güç koşullarla karşılaşmak zorunda kalmıştır. Kazan ve Sibirya uzak bölgelerine vagonlar vasıtasıyla götürülen savaş esirlerinin akıbeti gizemlidir. ${ }^{21}$ Birkaç cephede sürdürülen silahlı çatışmalarda, kayıp ve ağır yaralılar hariç, aralarında çok sayıda engelli bulunan 202 bin Osmanlı askerinin esir düştüğü iddiası ileri sürülmektedir. ${ }^{22}$ Söz konusu Galiçya, Filistin, Suriye, Irak, Hicaz ve Suriye cephelerinde esir kalan ve Britanya savaş kamplarına götürülenler Osmanlı Ordusu'nun gazileri ve mücahitleridir.

Birinci Dünya Savaşı süresince Büyük Britanya sömürgesi olan Mısır'da çok sayıda savaş esiri için toplama kampları kurulmuştur. Bu kamplarda savaş esirleri hastaneleri de mevcuttu. Kamplarda genelde İngiliz ordusu tarafindan Çanakkale, Filistin, Irak ve Yemen cephelerinde esir alınan Osmanlı askerleri, aralarında ise çok sayıda yaşlı, subay eşleri ve çocukları yerleştirilmiştir. Uluslararası Kızılhaç Örgütü tarafından savaş kamplarında esir düşen kişilerin durumunu kontrol etmek için Aralık 1916 ve Ocak 1917 tarihleri arasında Mısır'a üç temsilci (Dr. Blanchod, Thormeyer ve Scoch) gönderilmişti. Söz konusu heyet Seyid El Beşir

\footnotetext{
${ }^{18}$ I. Rebronja, MK olaković., Budi nešto da ne budeš ništa, Novi Pazar 2005, s. 75.

${ }^{19}$ Türk Silahlı Kuvvetleri Tarihi Osmanlı Devri Birinci Dünya Harbi İdari ve Lojistik, Cilt 4, Ankara 1985, s. 319.

${ }^{20}$ Nuri Köstüklü, “I. Dünya Savaşında Rusya'nın Ukrayna ve Diğer Bölgelerindeki Türk Savaş Esirlerine Dair Bazı Tespitler”, Atatürk Araştırma Merkezi Dergisi, Cilt XXVIII, Sayı 83, Ankara, Temmuz 2012, s. 4.

21 Yücel Yanıkdağ, Ottoman Prisoners of War in Russia 1914-1922, in: Journal of Contemporary History 34/1 (1999), s. 23-37, 72; Davis Gerald, Prisoner of War Camps as Social Communities in Russia: Krasnoyarsk, 19141921, in: East European Quarterly 21/2 (1987), s. 149.

${ }^{22}$ Cemalettin Taşkıran, Ana Ben Ölmedim, 4. Baskı, Türkiye İş Bankası Kültür Yayınları, İstanbul 2011, s. 353.
} 
(Kuveysna Kamp1), Ras-El-Tin, Kahire Kalesi, Heliopolis, Abbasiye Hastanesi, Maddi Kamp1, Bilbeis Kampı, Kahire Kızılay Hastanesini ve Turra Kampını ziyaret etmiştir. ${ }^{23}$

Bazı kaynaklara göre, esir düşen Osmanlı askerleri ilk olarak Kahire'nin güneyinde bulunan Maadi kampına getirildikten sonra diğer kamplara nakledilmiştir. Kızılay ifadelerine bakıldığında çok sayıda yanlış ve yetersiz bilgi göze çarpmaktadır. Bu dosyalarda az sayıda savaş esiri hakkında bilgiler bulunmaktadır. ${ }^{24}$ En geniş bilgiler Kızılhaç arşivlerinde bulunabilir ve içinde kanlı basur, verem, beri beri, humma, lekelihumma ve çeşitli bulaşıcı hastalıklardan ölen esirlerin sayısı çoğunlukla kaydedilmiştir. Koşullara uyum sağlayamayan önemli sayıda yaralı savaş esiri de görme yetisini kaybetmiştir.

Balkan Yarımadası'nda savaş sonrası ilişkilerin gidişatı Sırp-Hırvat ve Sloven Krallığı ile Osmanlı İmparatorluğu arasında diplomasinin gelişmesini zorlaştırmıştır. ${ }^{25} \mathrm{Bu}$ meyanda 1918 ve 1921 yılları arasında kayıp ve esir düşen askerlerin aranması süreci de devam etmiştir. Kayıp kişilerin aranmasını konu alan, bu günlere kadar korunmuş arşiv malzemelerine (dilekçeler, röportajlar) bakıldığında çok sayıda Yugoslav vatandaşının Avusturya-Macaristan, Bulgar veya Alman ordusu tarafından seferber edildiği veya esir alınıp Türkiye'ye gönderildikten sonra Mısır ve diğer yerlerdeki Britanya savaş esiri kamplarına ulaştığı göze çarpmaktadır. Elimize geçen bilgilere göre, aralarında çok sayıda engelli dâhil, en az 5192 Müslüman savaş esirinin kamplarda barınmış olduğu görülmektedir. ${ }^{26}$ Bunların büyük çoğunluğu Makedonya (Üsküp, ${ }^{27}$ Köprülü, Koçana, Kratova, Kumanova, ${ }^{28}$ Eğri Palanka, Radoviş, ${ }^{29}$ Isștip, ${ }^{30}$ Ustrumca, Manastır, Kavadar, ${ }^{31}$ Doyran, Pirlepe, Kalkandelen, ${ }^{32}$ Gostivar, ${ }^{33}$ Debre, Kirçova, ${ }^{34}$ Struga, ${ }^{35}$ Ohri $^{36}$ ), Kosova (Priştine, Prizren, ${ }^{37}$ Ferizovik, Vulçıtın, Gilan, Mitroviça, İpek) ${ }^{38}$, Sancak (Novi Pazar, ${ }^{39}$ Rojaye, Tırgovişte, Seniçe, Nova Varoş, Prepol, Taşlıca, Priboy, Brodareva, Akova, Berane), Güney Surbistan (Buyanovçe, Preşova ${ }^{40}$ ), Podgorica (Karadağ) ${ }^{41}$ veya bu civardan gelmiştir.

\footnotetext{
${ }^{23}$ C. Taşkıran, a.g.e., s. 176.

${ }^{24}$ C. Taşkıran, a.g.e., s. 187.

${ }^{25}$ Esir alınan ve savaş kamplarına gönderilen kişilerin vatana geri gönderilmesi için 6 Aralık 1918 ve 10 Ekim 1919 tarihleri arasında Sırp, Hırvat ve Sloven Krallığı tarafindan askerî ataşe görevine Sırp yarbayı Dragomir Nikolayeviç atanmıştır. Dışişleri Bakanlığı tarafından ise sivil temsilcisi olarak Radomir Şaponyiç görevlendirilmiştir. (Bakınız: Тодоровић Десанка, Став Краљьевине СХС према Мировно уговору са Турском у Севру 1920; Bakınız: Историја XX века (Зборник радова, XI, Институт за савремену историју, Београд 1920, s. 232.) 12 Temmuz 1920 tarihinde verilen kararla atanan Radomir Şaponyiç 1923 yılın Ocak ayında maslahatgüzar görevini tamamladığında, başında Dr. Yanaçiye Dimitriyeviç bulunan Sırp, Hırvat ve Sloven Krallığı Genel Konsolosluğu kurulmuştur. (Kaynak: Arhiv Jugoslavije, 370-52-134, pov. br. 58, 340; i: 37o-51-133, pov. br. 35 od 29. I. 1923.) Altı ay önce, 6 Haziran 1922 tarihinde İzmir'de Sırp, Hırvat ve Sloven Krallığı Konsolosluğu açılmıştır.

${ }^{26}$ Arhiv Jugoslavije, Beograd/ Yugoslavya Arşivi, Belgrad, Fond/Dizi: AJ 370-57-250.

${ }^{27}$ Svilare, Elovo, Umovo, Dirjilovo (Aynı: 370-57-177.).

${ }^{28}$ Tabanovça, Mateyçe, Novo Selo (Arhiv Jugoslavije, Beograd/ Yugoslavya Arşivi, Belgrad, Fond/Dizi: 370-57150.

${ }^{29}$ Tabanovça, Mateyçe, Novo Selo (Arhiv Jugoslavije, Beograd/ Yugoslavya Arşivi, Belgrad, Fond/Dizi: 370-6-88.

${ }^{30}$ Seydili Haci (AY Belgrad, 370-6-91.).

31 Tikveş, Kuşevçe, Tinyanik (AY Belgrad, 370-57-44).

32 Teartze, Şipkovitsa, Urviç, Neraşti, Zlatina (Arhiv Jugoslavije, Beograd/ Yugoslavya Arşivi, Belgrad, Fond/Dizi: 370-57-155.).

${ }^{33}$ Forina, Debreşe, Semnitze, Reçan, Dobri Dol, Kalişta (Aynı: 370-57-177.).

${ }^{34}$ Forina, Debreşe, Semnitze, Reçan, Dobri Dol, Kalişta (Aynı: 370-57-163.

${ }^{35}$ Lyubenişte (Yugoslavya Arşivi Belgrad, Fond/Dizi: 370-57-166.)

${ }^{36}$ Lyubenişte (Yugoslavya Arşivi Belgrad, Fond/Dizi: 370-57-63.

${ }^{37}$ Lyubenişte (Yugoslavya Arşivi Belgrad, Fond/Dizi: 370-57-173.

${ }^{38}$ Yugoslavya Arşivi Belgrad, Fond/Dizi: 370-57- 58.

${ }^{39}$ Yugoslavya Arşivi Belgrad, Fond/Dizi: 370-57- 22.

${ }^{40}$ Yugoslavya Arşivi Belgrad, Fond/Dizi: 370-57- 167.

${ }^{41}$ Yugoslavya Arşivi Belgrad, Fond/Dizi: 370-57- 77.
} 
Geniş arşiv malzemesinde Osmanlı müttefikleri veya yakın cephelerde ele geçirildikten sonra Britanya savaş kamplarına yerleştirilen Yugoslav savaş esirleri hakkında bilgiler yetersizdir. İstanbul ve İzmir'de bulunan Sırp-Hırvat ve Sloven Krallığ temsilcilerine, Britanya, Almanya ve Fransa büyükelçiliklerine, Kızılhaç ve Kızılay temsilcilikleri adreslerine çok sayıda maddi yardım talebi ve vatana geri dönüş dilekçeleri ulaşmıştır.

\section{Esaretten Geri Dönen Gönüllülerin Akıbeti}

Batı Rumeli'nin dört tarafindan gelen Türk, Arnavut, Roman, Boşnak, Goralı, Torbeş veya diğer etnik unsurlara ait tecrübesiz genç Müslüman erkekleri, hiç savaş hazırlığ görmeden dünyanın o zamana kadar tanık olmadığı kanlı çatışmaların içine derhâl sokulmuştu. Bunların büyük çoğunluğu tanımadığı ülkelerde cephelerde ölüme gönderilmişti. Galiçya, Gelibolu, Romanya, İtalya veya Mısır savaş kamplarında, bilinmeyen ve yabancı ülkelerde, evlerinden ve ailelerinden uzakta, yeterli eğitimi veya okuryazarlığı bile olmadan, emirlerin verildiği Almanca, Türkçe veya başka bir dili hiç anlamadan, savaş amaçlarını hiç bilmeden Britanya İmparatorluğu esirleri olmuşlardır. Uluslararası muhabirlerin ve ajansların "mezbaha" diye betimledikleri cephelerin en feci mevkilerine atanmışlardır. Kemikleri büyük çoğunlukla savaş mekânlarında kalan bu gönüllülerin bir bölümü esir düşmüş, küçük bir kısmı evlerine tekrar geri dönebilmiştir. Savaştan geri dönen çok sayıda gönüllü asker engelli olarak hayatına devam etmiş bu nedenle psikolojik sarsıntılara yatkın hâle gelmişlerdir.

Seferberlik sürecinde gönüllülerin adları ve kimlikleri üzerinde kesin istatistik yapılmamıştır. Bilgiler genelde savaş sonrasında aileleri tarafından toplanmıştır. Rivayete göre bunlar genelde dürüst insanlardı ve aralarında genelde yoksul ve ırgat olarak çalışanların sayısı büyüktü. Bazıları ailelerini besleyebilecek para kazanmak için savaşa katılmıştı. Ştavik ilçesinden gelen gönüllülerin sayıs1 250-300 civarındaydı. ${ }^{42}$ Bunların bir bölümü Bağdat etrafındaki cepheye gönderildikten sonra kısa zaman içinde İngilizler tarafindan esir alınmıştır. Benzer örnek olarak 8 yıl süren esirlikten sonra evine geri dönen Sadriya Sinanoviçi alabiliriz. ${ }^{43}$

Geri dönecekleri hakkında umutlar gittikçe sönüyordu. Herhangi bir gönüllünün geriye döndügü haberini alan ihtiyar anne babalar hüzünle kendi çocuklarını karşılamaya hazırlanıyorlardı. Akıbetleri hakkındaki gerçekler anavatana güçlüklerle ulaşabiliyordu, hatta aralarında hiç dönmeyenler de vardı. Üzüntü içinde boğulan köylerde hayat tamamen durmuştu. Dügü̈nleri, şenlikleri geçmişte kalan bu köylerde savaştan dönmeyi başaran gönüllülerde Hristiyan hükûmetin kendilerinden intikam alacağı endişesi artıyordu. Sivil ve askerî yetkililerden saklanıyorlardı. Bütün bölgenin savaş uçurumu içine düştüğü belliydi. Uzak yerlerden gelen nadir mektupları okuyacak, anlayacak ve cevaplandıracak kişilerin de sayısı düşüktü. Böyle bir durum sıradan iletişimi de zorlaştırıyordu. Umutsuzca köylere geri dönenlerin sayısı düşüktü. Bir gün Tutin kırsalında yaşayan Smail Drajanin adında bir kişiye bilmediği yerden mektup gelmişti. Oğlu tarafindan gönderilmiş olduğunu zanneden Smail bu kâğıttan ayrılamamış ve bu mektubu okuyacak birini bulabilmek için günlerce dolaşmaktan vazgeçmemişti. ${ }^{44}$

1918 yılın ortalarında yayımlanan gazetelerin haberlerine göre cephelerde, toplama kamplarında, iş kamplarında ve fabrikalarda 500-600 civarında Sancak askerinin bulunduğu bildirilmişti. ${ }^{45}$ "Nova Zora" gazetesinin yazdıklarına göre 29 Ekim 1918 tarihinde Almanya teslim olmuş ve ateşkes koşullarını kabul etmiştir. Belgenin ikinci kısmına göre savaşın son günlerinde tutuklanmış ve esir alınmış askerlerin serbest bırakılması yükümlülüğü belirlenmişti. ${ }^{46}$ Çok sayıda gönüllünün çilesi de biliniyordu. Savaş karşııtı propaganda geriye

\footnotetext{
${ }^{42}$ Istorijski Arhiv „Ras” - Novi Pazar, Fond SNO i SK KPS Tutin, dok. 01-br. 5982/1, 14. IX. 1960.

43 Sutković Esad N., Radetina i Radetinci... 69.

44 Popović V., Peštersko-štavički vihori (Hronika), Beograd 2003., 93.

${ }^{45}$ Nova zora, br. 15-18, Beograd (25. - 28. X. 1918.).

${ }^{46}$ Nova zora, br. 15-18, Beograd (29. X. 1918.).
} 
dönüş umutlarını uyandırıyordu. 1 Aralık 1918 tarihinde Sırp-Hırvat ve Sloven Krallı̆̆ı'nın kurulduğunu bildiren haberler askerlerin ve savaş esirlerinin evlerine geri dönüşleri üzerinde beklentileri arttırmıştır.

Hayatta kalmayı başaran gönüllülerin küçük bir bölümü savaştan sonra Osmanlı birliklerinde kalmıştır. Çoğunluğunun akıbeti hâlâ bilinmiyor. Anavatanda ikamet eden gönüllülerin aileleri yeni Yugoslav iktidarına inanmayıp intikamdan korkmuştur. Geriye dönen gazilerin bazıları yol üzerinde Sırplar tarafından kurulan pusularda öldürülmüştür. Yeni devlet yetkilileri tarafından devlet düşmanları olarak muamele gören Rumelili gönüllülerin adları uzun zaman boyunca Yugoslav Polis arşivlerinden silinmemiş hatta bazılarının izi tamamen kaybolmuştur. Vatanlarına aşağılanmış şekilde ve dehşet içinde dönen gönüllüler, içlerinde hayatları boyunca aldatılmışlık duygusunu yaşamaya devam etmişlerdir. Kendi kaderlerine terk edilmiş, maddi durumu kötü, savaştan tazminat veya engelli maaşı alamayan gönüllüler yaşadıklarını paylaşmayı reddetmiş̧lerdir. Kişisel mağlubiyet, tecrit ile yabancıların ahlaki sorumluluklarını ölene kadar taşımışlardır.

\section{Sonuç}

Osmanlı Ordusu içinde mücadele eden Batı Rumeli asıllı Müslüman gönüllüleri ve diğer savaş gazilerinin Galiçya, Romanya, Yemen, Filistin, Irak, İran, Suriye, Mısır, Arap Çölü cephelerinden geri dönüşleri değiş̧ik maceralarla doluydu. Maddi ihtiyaçları, kişisel evrakları ve paraları olmayan bu insanlar Sirp-Hırvat ve Sloven Krallı̆̆ diplomasi temsilciliklerine başvurmak zorunda kalmışlardır. Büyük cesaret ve dürüstlük gösterdikleri cephelerin ön saflarından Britanya'nın Mısır'daki savaş esirleri kamplarına gönderilmişlerdir. Savaşın bitmesiyle birlikte unutulan gaziler ve gönüllüler İstanbul'a veya İzmir'e gönderilmiştir ve buradaki konsoloslukların önünde uzun zaman önce terk ettikleri anavatanları Rumeli ve geride bıraktıkları aileleriyle bağlarını ispatlamak zorunda kalmışlardır. Feci duruma düşürülen, vatansız kalan savaş esirleri Sırp-Hırvat ve Sloven Krallığı temsilcileri önünde yeni kurulan devlete karşı "hissettikleri sadakati" kanıtlamak durumuna getirilmişlerdir. İmkânsız koşulları yerine getirebilmek için çok sayıda dilekçe, form ve türlü yazılı kanıt hazırlamak için çaba sarf etmişlerdir. Elimize geçen bu yazıların bazılarına bakıldığında, Britanya savaş esirleri kamplarına nasıl ulaştıklarını anlatmaya çalıştıkları görülmektedir. Çoğunluğu AvusturyaMacaristan ve Bulgaristan Çarlığı ordusu tarafından zorunlu seferberliğe tabi tutulup evlerinden uzak cephelere gönderildiği ardından esir olarak Mısır'daki İngiliz savaş kamplarına getirildiğini anlatmışlardır. Geriye dönüşleri ise aylar süren idari süreçten daha zor ve belirsizdi. Azimleri ve vatanları için duydukları sevgi bütün engelleri, yaraları ve korkuları yenmiştir. Savaş korkuları tarafindan ezilen ve travmalar içinde boğulan bu insanlar hayatlarının sonuna kadar toplumdan soyutlanmış olarak yaşamlarını sürdürmüşlerdir. Kovulma endişesi ve korkusu onları hiç terk etmedi. Büyük bir bölümü ise evlerine geri dönüşleri esnasında gayrimüslim terör örgütleri tarafından hazırlanan pusular içinde hayatlarını kaybetmişlerdir. Diğer bilgiler ise bir zamanki Osmanlı vatanı için hissettikleri sevgilerinden ötürü unutulan ve terk edilen bu nesil hakkında kitaplar ve nadir yazılardan geliyor.

\section{Kaynakça}

\section{Arşiv Kaynakları}

Arhiv Jugoslavije, Beograd/ Yugoslavya Arşivi, Belgrad, Fond/Dizi: AJ 370-57-245; 370-6112; 370-52-134; 370-51-133.

Istorijski Arhiv „Ras” - Novi Pazar, Fond SNO i SK KPS Tutin, dok. 01-br. 5982/1, 14. IX. 1960. 


\section{Kitap ve Makaleler}

Akçakayalıoğlu, Cihat, Birinci Dünya Harbi, c. VII - Avrupa Cepheleri, 1. Kısım (Galiçya Cephesi), Genelkurmay Başkanlığı, Ankara 1967.

Aleksić-Pejaković Lj., Balkan balkanskim narodima - između legitimističkog i nacionalnog principa (Balkanlar Balkan Milletlerine Aittir - Legitimist İle Milli İlkesi Arasinda), u: Zbornik: "Balkan, islam i velike sile (Balkan, İslam ve Büyük Güçler)", Beograd 1998.

Bandžović, Safet, Iseljavanje Bošnjaka u Tursku (Boşnakların Türkiye’ye Göçü), knj. 1, Sarajevo 2006.

Bebler A., Propuštena prilika za istorijski sporazum (Tarihsel Antlaşmanın Kaçırıldı̆̆ı Bir Firsat), u: Helsinška povelja, br. 119-120., Beograd maj-juni 2008.

Halid, H., Borba polumjeseca i krsta (Hilal ile Haç Arasındaki Mücadele), knj. I, Mostar 1913.

Koničanin, Omer, Sjećanja (Hatıralar), Istorijski arhiv „Ras”, Novi Pazar 1988.

Köstüklü, Nuri, “I. Dünya Savaşı’nda Rusya'nın Ukrayna ve Diğer Bölgelerindeki Türk Savaş Esirlerine Dair Bazı Tespitler”, Atatürk Araştırma Merkezi Dergisi, Cilt XXVIII Sayı 83, Ankara Temmuz 2012.

Mušović, Ejup, Etnički procesi i etnička struktura stanovništva Novog Pazara (Etnik Süreçler ve Yeni Pazar Nüfusunun Etnik Yapısi), Etnografski institut SANU, Beograd 1979.

Nova zora (Yeni Şafak), br. 15-18, Beograd (25. - 28. X. 1918.); (29. X. 1918.)

Popović, V., Peštersko-štavički vihori (Hronika) (Peşter-Ştavik Esintileri (Kronik), Beograd 2003.

Rebronja, I., Kolaković M., Budi nešto da ne budeš ništa (Hiçbir Şey Olma Bir Şey Ol), Novi Pazar 2005.

Sayg1lı, Hasib, "Birinci Dünya Harbinde Rumelinden Osmanlı Ordusuna Müslüman Gönüllü Katılımları”, Hacettepe Türkiyat Araştırmaları, 18 (2013).

Škrijelj, Redžep, "Đurumlije” - Sanjak Bosniak Volunteers in the Turkish Military Orders from Gallipoli to Galicia (1916-1918), (Gönüllüler - Gelibolu’dan Galiçya’ya Kadar Türk Askerî Birliklerinde Sancak Boşnak Gönüllüleri (1916-1918) in: Bosnia \&Hercegovina International Balkan Annual Conference (IBAC), book ser. 3, İstanbul 2015.

Škrijelj, Redžep, Sandžački Bošnjaci u Makedoniji (1918-1945) (Makedonya'daki Sancak Boşnakları, 1918-1945), u: Seobe kao sudbina, Istorijska čitanka za potomke bošnjačkih muhadžira u Makedoniji, Citypres, Skopje 2011.

Šutković, Esad N., Radetina i Radetinci (Radetina ve Radetinalılar), Rožaje 2004.

Taşkıran Cemalettin, Ana Ben Ölmedim, 5. Baskı, Türkiye İş Bankası Kültür Yayınları, İstanbul 2015.

Temizer, Abidin, "Karadağ'da Öteki Sorunu: Müslümanlar", History Studies, Vol. 5, Issue 3, May 2013, ss. 223-40.

Temizer, Abidin, "Montenegro in the First Balkan War“, Annals Series on History and Archeology, Vol. 5, Issue 1, 2013, s. 76.

Temizer, Abidin, "Şiirsel Gerçeklikten Tarihi Gerçekliğe Balkan Uluslarının Bağımsızlık Çözümlemesi: Hakkın Sesleri”, Uluslararası Mehmet Akif Ersoy Sempozyumu,SanatıKişiliği-Milli Mücadeledeki Yeri (Bildiri Kitabı), Balıkesir 2011, ss. 353-63. 
Тодоровић Десанка, Став Краљевине СХС према Мировно уговору са Турском у Севру 1920 (Todoroviç Desanka, SHS Krallı̆̆ı'nın Sevr Antlaşmasına Karşı Görüşü); Историја XX века (Зборник радова, XI, Институт за савремену историју, Београд 1920.

Türk Silahlı Kuvvetleri Tarihi Osmanlı Devri Birinci Dünya Harbi İdari ve Lojistik, Cilt 4, Ankara 1985.

Yanıkdağ, Yücel, Ottoman Prisoners of War in Russia 1914-1922 (Rusya'daki Osmanlı Savaş Esirleri, 1914-1922), in: Journal of Contemporary History 34/1 (1999), 23-37, 72; Gerald Davis, Prisoner of War Camps as Social Communities in Russia: Krasnoyarsk, 19141921, in: East European Quarterly 21/2 (1987). 